\title{
SHELTER COMPETITION BETWEEN TWO INVASIVE CRAYFISH SPECIES: A LABORATORY STUDY
}

\author{
F. ALONSO (*) AND R. MARTÍNEZ
}

\begin{abstract}
Centro de Investigación Agraria de Albadalejito. Junta de Comunidades de Castilla-La Mancha. Crta. Toledo-Cuenca, km 174. 16194 Cuenca, Spain. E-Mail: falonso@jccm.es

$\left(^{\star}\right)$ To whom correspondence should be addressed.
\end{abstract}

Reçu le 23 juin 2005

Accepté le 30 décembre 2005

Received June 23, 2005

Accepted December 30, 2005

\begin{abstract}
Alien crayfishes represent a common threat to aquatic ecosystems. Their spread in Europe is leading to more frequent contacts between different invasive species populations. Shelter can be an important factor in the resulting interactions. A laboratory experiment was designed to analyse the competition for shelter in similarly sized males of two species that show an invasive behaviour in Spain, Pacifastacus leniusculus and Procambarus clarkii.
\end{abstract}

We carried out 24 heterospecific, six-hour trials, with 30 min behavioural observations per hour. Most often, red swamp crayfish were both the first $(70.8 \%)$ and the long-term winner (62.5\%). Usually, the long-term winner was the first winner. Whenever shelter was occupied, a passive behaviour by unsheltered individuals was more frequent in signal crayfish than in red swamp crayfish. When both were unsheltered, signal crayfish displayed more often a passive behaviour.

Although the observed behaviour might be explained as the result of dominance by the red swamp crayfish over the signal crayfish, shelter availability and class, as well as different growth patterns and population size structures, could change the intensity and the outcome of the encounters in the wild, where signal crayfish usually reach larger sizes than red swamp crayfish.

Key-words: competition, shelter, crayfish, Pacifastacus leniusculus, Procambarus clarkii, invasive species.

\section{COMPÉTITION POUR LES REFUGES EN CONDITIONS DE LABORATOIRE ENTRE DEUX ESPÈCES INVASIVES D'ÉCREVISSES}

\section{RÉSUMÉ}

Les écrevisses exotiques représentent une menace pour les écosystèmes aquatiques. Leur dispersion généralisée en Europe a pour conséquence une augmentation de la fréquence de contact entre différentes populations d'espèces invasives. La disponibilité des refuges est un facteur important du résultat de ces interactions. Une expérimentation en laboratoire a été conçue pour analyser la compétition pour les refuges entre mâles de 
taille identique de deux espèces d'écrevisses exotiques qui montrent un comportement envahisseur en Espagne: Pacifastacus leniusculus et Procambarus clarkii.

Nous avons mis en place 24 lots interspécifiques de 6 heures, avec des périodes d'observation de 30 minutes par heure. Dans 70,8\% des cas, les écrevisses de Louisiane ont été les premières à occuper les abris, et aussi les vainqueurs sur le long terme dans $62,5 \%$ des cas. En général, le premier arrivé a gardé sa place au long-terme. Lorsque l'abri était occupé, les écrevisses signal ont montré plus souvent un comportement passif que les écrevisses de Louisiane. Lorsque des spécimens des deux espèces étaient sans abri, les écrevisses signal ont fait preuve plus souvent d'un comportement passif.

Bien que les comportements observés puissent être interprétés comme un avantage des écrevisses de Louisiane sur les écrevisses signal, la disponibilité et le type des refuges ainsi que des différences dans la structure et dans la croissance des populations peuvent modifier l'intensité et l'issue des rencontres en milieux naturels, où les écrevisses signal atteignent généralement une taille supérieure à celle des écrevisses de Louisiane.

Mots-clés : compétition, refuge, écrevisse, Pacifastacus leniusculus, Procambarus clarkii, espèce invasive.

\section{INTRODUCTION}

Although the signal crayfish Pacifastacus leniusculus (Dana, 1852) and the red swamp crayfish Procambarus clarkii (Girard, 1852) have been introduced into Spain nearly at the same time (1973 and 1974 respectively), thirty years later their distribution pattern is different probably due to different fisheries and commercialisation regulations (ALONSO et al., 2000). The red swamp crayfish has spread quicker and shows a wider distribution along the country, being present in all the Spanish provinces. Signal crayfish distribution was more restricted, but recent changes in its management (i.e. fishing for this species was first allowed in Spain in 1994, and unlimited access fishing in some areas since 2000) have accelerated its dispersal, especially in Central Spain. Both are now the most common crayfishes found in the Iberian Peninsula, and the localities where they cohabit are increasing.

The study of the competition between these two species may provide an understanding of the mechanisms involved in the success of invasive aquatic species and offers a baseline for crayfish management in the Iberian Peninsula. For example, without any scientific support, some Fisheries Agencies are stocking signal crayfish in several areas to act as an "upstream barrier" against the spread of red swamp crayfish (CUÉLLAR and CUÉLLAR, 2000). Instead, these stockings have eased the spread of the signal crayfish to new areas as a result of illegal introductions. Both species carry and transmit crayfish plague to European crayfishes, outbreaks of which are still taking place in Spain (DIÉGUEZ-URIBEONDO et al., 1997; DIÉGUEZ-URIBEONDO, pers. com.), but also represent a serious conservation problem to the aquatic ecosystems independently of their harm to Austropotamobius pallipes s.I. populations (CHARLEBOIS and LAMBERTI, 1996; GUAN and WILES, 1997; STENROTH and NYSTROM, 2003; LIGHT, 2005).

Amongst the factors involved in invasion and replacement processes we can find interspecific differences in survival and growth, inter- and intraspecific predation, aggressive interactions, reproductive interference, competition for food, transmission of pathogens and parasites and competition for shelter (ELLIS, 1999; FIGLER et al., 1999; HOLDICH and DOMANIEWSKI, 1995; LINDQVIST et al., 1999; PEEKE et al., 1995; GUIASU et al., 1997; HILL and LODGE, 1999;). Niche characteristics and occupation, as well as the result of the above-mentioned interactions, affect the rates of replacement and the rhythm of invasions, which are not unidirectional processes (HILL and LODGE, 1999). 
Shelter availability is one of the key features governing crayfish habitat quality. It has been shown to influence directly the individual survival of crayfish, lowering the risk of predation (BLAKE et al., 1994; GARVEY et al., 1994, SÖDERBACK, 1994). Shelters may also attract mates (BERGMAN and MOORE, 2003) and allow some species, such as P. clarkii, to withstand extreme environmental conditions (HUNER and BARR, 1991). Furthermore, there is evidence that shelters are limited in the wild (BOVBJERG, 1970; HILL and LODGE, 1994) and competition for them has been documented both at interand intraspecific levels (see GHERARDI, 2002, for a review), being an important factor in the replacement between crayfish species. Male crayfish are usually dominant over the other sex and participate more often in aggressive interactions (GHERARDI et al., 1999; RANTA and LINDSTRÖM, 1993). Their bigger chelae should place them in advantage, for example, when fighting for shelter (LEVENBACH and HAZLETT, 1996).

Up to date, most of the studies on this topic have been carried out either between different native crayfish or between dyads of native/non-native ones. As a part of a wider study dealing with the interaction between red swamp and signal crayfish, in this paper we analyze shelter competition between adult males of these two nonindigenous species in a controlled laboratory environment.

\section{MATERIAL AND METHODS}

Male crayfish were collected in the nearby river Júcar from different locations (signal crayfish: UTM 30TWK 5738 44415; red swamp crayfish: UTM 30TWK 5745 44392) and kept in our laboratory for at least $15 \mathrm{~d}$ in acclimatization. Maintenance conditions were the same as those used during the experiment: photoperiod ( $14 \mathrm{~h}$ light/10 $\mathrm{h}$ darkness) and water temperature $\left(18^{\circ} \mathrm{C}\right.$ during light phase, $17^{\circ} \mathrm{C}$ during dark phase), selected to reproduce local conditions in summer. Until used in the trials, individuals were housed in separated $150 \mathrm{I}$ tanks for each species and fed with commercial trout pellets. Each crayfish was individually marked in the top of the carapace with a waterproof pen.

To avoid obvious biases, only individuals in intermoult stage, with both chelipeds in good condition and with no evident mutilations in antennae and other appendages, were used for the trials. In addition, only Form I red swamp crayfish were used. We selected pairs with differences in cephalothorax length and in wet weight less than $10 \%$ and $20 \%$, respectively. Cephalothorax length was measured from the tip of the rostrum to the end of cephalothorax with a digital Vernier caliper to the nearest $0.1 \mathrm{~mm}$. Wet weight was obtained to the nearest $0.1 \mathrm{~g}$. Mean sizes and weights are summarized in Table I. Crayfish were isolated for $24 \mathrm{~h}$ prior to test in similar aquaria than those used in the trial and were starved. All crayfish were used only once.

\section{Table I}

Mean cephalothorax lengths and wet weights of the crayfish used in our observations. Values are reported as means \pm standard deviations, minimummaximum range given in brackets.

\section{Tableau I}

Longueur moyenne du céphalothorax et poids humides moyens des écrevisses utilisées dans nos observations. Les valeurs sont présentées sous le format moyenne \pm écart-type, valeurs maximales et minimales en parenthèses.

\begin{tabular}{|l|l|c|}
\hline \multicolumn{1}{|c|}{ Species } & Cephalothorax length $(\mathrm{mm})$ & Weight $(\mathrm{g})$ \\
\hline Red swamp $(\mathrm{n}=24)$ & $46.98 \pm 1.83(43.9-50.2)$ & $23.87 \pm 2.72(19.2-28.9)$ \\
\hline Signal $(\mathrm{n}=24)$ & $44.07 \pm 2.56(40.1-48.1)$ & $24.79 \pm 4.17(17.4-30.9)$ \\
\hline
\end{tabular}


We modified the methods used by ELVEY et al. (1997) and VORBURGER and RIBI (1999). Trial setup consisted of a 28 I aquaria, refilled with 20 I of tap water for each test with a fine gravel bottom layer of $\mathrm{ca} .1 \mathrm{~cm}$ to simulate natural conditions. Each aquarium contained an aerator and a shelter, sized to the used individuals. After preliminary trials, we selected a PVC pipe $(120 \mathrm{~mm}$ in length and $40 \mathrm{~mm}$ in diameter) fitted inside the central hole of a brick $(210 \times 130 \times 70 \mathrm{~mm})$, which provided stability. The remaining holes of the brick were blocked so that they could not give additional shelter. Two opaque mobile plastic sheets were placed in the aquaria to separate each crayfish from the shelter and from the rival (Figure 1). An hour after the beginning of the light phase, the selected heterospecific pair of crayfish was placed in the aquarium and after 10 min both separators were simultaneously lifted. The behaviour of crayfish was videotaped for $6 \mathrm{~h}$ with a PANASONIC ${ }^{\text {TM }}$ NV-DSD15EG VHS recorder.

During each 30 min observation period we recorded: a) the position of both crayfish relative to the shelter (in/out), b) the behaviour of the unsheltered crayfish (according to Table II). We also recorded the initial winner, defined as the first individual that occupies the shelter, the time in seconds needed to do so, and the long-term winner. This was defined as the crayfish occupying the shelter for more than $50 \%$ of the $30 \mathrm{~min}$ observations (ELVEY et al., 1997).

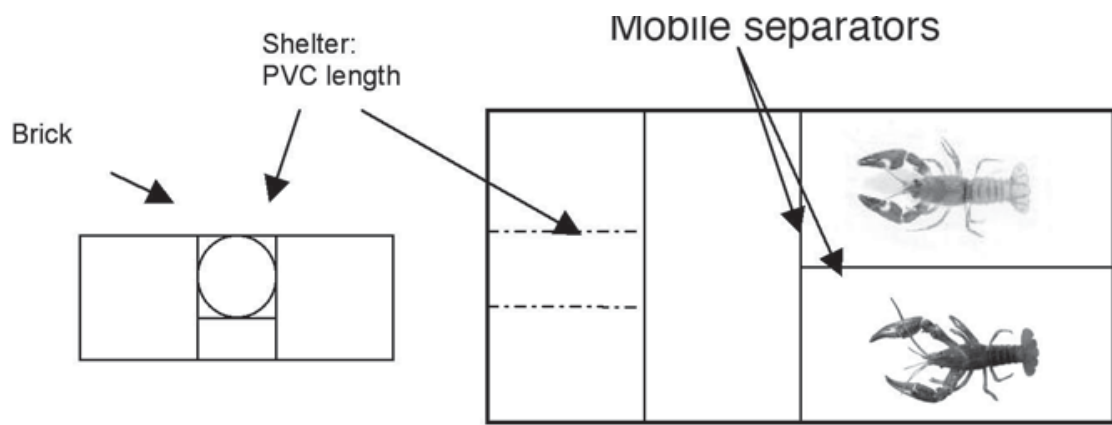

Shelter front view

Vertical view

\section{Figure 1}

Scheme of the experimental aquarium.

\section{Figure 1}

Schéma de l'expérience.

Table II

Description of the observed behaviour.

\section{Tableau II}

Description des comportements observés.

\begin{tabular}{|l|l|}
\hline Behaviour & Description \\
\hline Tension contact & $\begin{array}{l}\text { Contact between both crayfish, involving chelae strike, pushing or } \\
\text { grabbing. }\end{array}$ \\
\hline Active & $\begin{array}{l}\text { Crayfish moving around the aquarium, without physical contact } \\
\text { with the sheltered crayfish, or motionless but erect. }\end{array}$ \\
\hline Passive & Motionless crayfish, holding its body flat against the substrate \\
\hline
\end{tabular}


The trials were compared using U Mann-Whitney tests for independent samples, and deviations from expected binomial distribution (i.e.: equal use of shelter by both species) were tested with chi-square tests. Time needed to occupy the shelter was transformed using a logarithmic transformation prior to ANOVA to meet normality. $2 \times 2$ contingency tables were analysed with Fisher exact test. When appropriate, the results of contingency tables were grouped to avoid violating assumptions of the tests or to facilitate our interpretation.

\section{RESULTS}

A total of 24 trials were carried out. Red swamp crayfish was the first winner for shelter in $70.8 \%$ of the trials (Chi-square, Yates correction $=3.375, p=0.065$ ), although the two species did not differ in the average time needed to occupy the shelter by the first winner (ANOVA: $F_{1,22}=1.68 ; p=0.2087$ ) (Table III, Figure 2). The red swamp crayfish was the long-term winner species in $62.5 \%$ of the trials (Chi-square, Yates correction $=2.042$, $p=0.1530$ ). In trials with definitive winners, no significant difference was found between the first winner and the long-term winner $(U=28.5 ; n=21 ; p=0.1990)$ (Table III). In 58.3\% of the observed cases the first winner remained inside the shelter during the whole trial.

Table IV shows the behaviour displayed by crayfish in and outside the shelter. While outside, the red swamp crayfish adopted a passive behaviour significantly more often than the signal crayfish (two-tailed Fisher exact test, $p<0.0000$ ). Tension contacts did not vary with the species in the shelter (two-tailed Fisher exact test, $p=0.2870$ ). In 11 observations $(3.82 \%)$ both crayfish were found sharing the shelter, despite its small size.

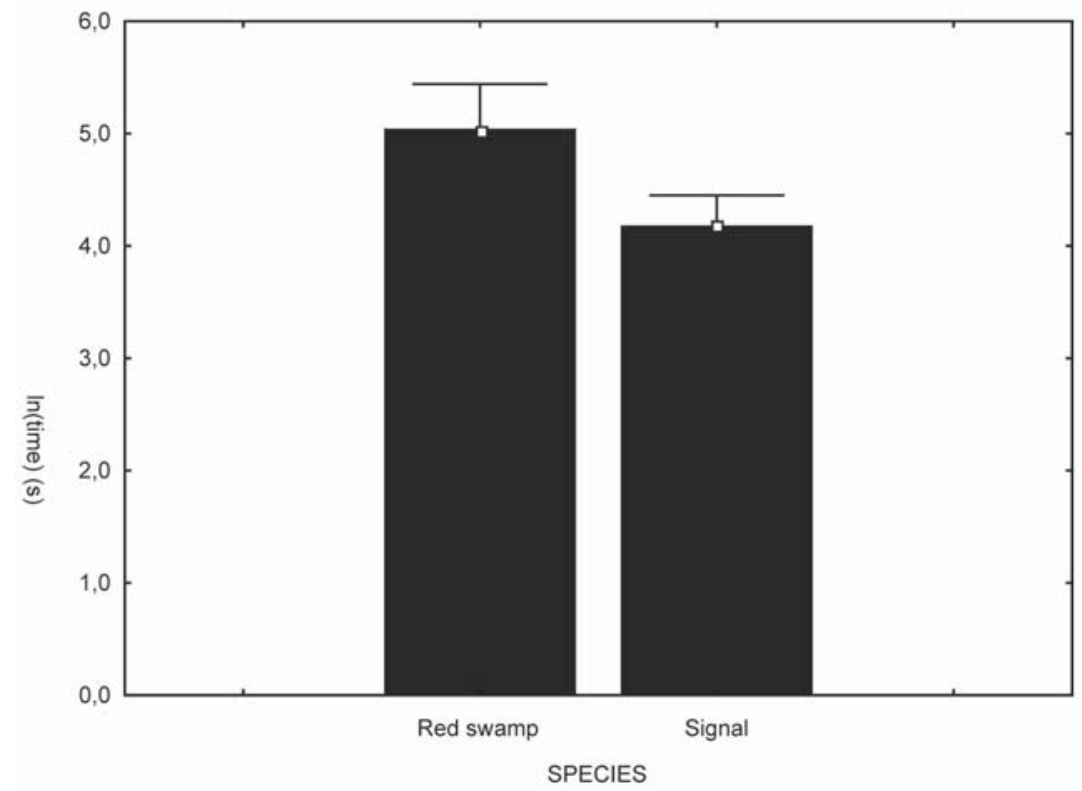

\section{Figure 2}

Length of time before the first occupancy of the shelter by the first winner (means \pm standard errors).

\section{Figure 2}

Temps passé jusqu'à l'occupation du refuge par le premier occupant (moyenne \pm erreur standard). 
Table III

Comparison between initial and long-term outcomes of the trials.

Tableau III

Comparaison entre les vainqueurs initiaux et à long terme des essais.

\begin{tabular}{|c|l|r|r|r|r|}
\cline { 3 - 6 } \multicolumn{2}{c|}{} & \multicolumn{3}{c|}{ Long term winner } & \multicolumn{1}{c|}{} \\
\cline { 3 - 6 } \multicolumn{2}{c|}{} & Red swamp & \multicolumn{1}{c|}{ Signal } & \multicolumn{1}{c|}{ None } & \multicolumn{1}{c|}{ Total } \\
\hline \multirow{2}{*}{$\begin{array}{c}\text { Initial } \\
\text { winner }\end{array}$} & Red swamp & $13(54.17 \%)$ & $2(8.33 \%)$ & $2(8.33 \%)$ & $17(70.83 \%)$ \\
\cline { 2 - 6 } & Signal & $3(12.50 \%)$ & $3(12.50 \%)$ & $1(4.17 \%)$ & $7(29.17 \%)$ \\
\hline & Total & $16(66.67 \%)$ & $5(20.83 \%)$ & $3(12.50 \%)$ & $24(100.00 \%)$ \\
\hline
\end{tabular}

\section{Table IV}

Observed behaviour of unsheltered crayfish when shelter was occupied by the rival. In 11 observations both crayfish shared the shelter.

\section{Tableau IV}

Comportements observés chez les écrevisses sans abri lorsque le refuge est déjà occupé par un rival. Dans 11 cas les deux écrevisses ont partagé l'abri.

\begin{tabular}{|l|c|c|c|}
\hline \multirow{2}{*}{ Sheltered crayfish } & \multicolumn{3}{|c|}{ Non-sheltered crayfish behaviour } \\
\cline { 2 - 4 } & Tension contact & Active & Passive \\
\hline Red swamp $(n=193)$ & $13(6.74 \%)$ & $51(26.42 \%)$ & $129(66.84 \%)$ \\
\hline Signal $(n=64)$ & $7(10.94 \%)$ & $38(59.38 \%)$ & $19(29.69 \%)$ \\
\hline Total $(n=257)$ & $20(7.25 \%)$ & $89(32.25 \%)$ & $148(53.62 \%)$ \\
\hline
\end{tabular}

\section{Table V}

Observed behaviours of crayfish when both were outside the shelter (n.o.: not observed).

\section{Tableau V}

Comportements observés chez les écrevisses lorsque les deux sont hors du refuge (n.o. : non observé).

\begin{tabular}{|l|l|c|c|c|}
\cline { 3 - 5 } \multicolumn{2}{c|}{} & \multicolumn{3}{c|}{ Signal } \\
\cline { 3 - 5 } \multicolumn{2}{c|}{} & Tension contact & Active & Passive \\
\hline \multirow{3}{*}{$\begin{array}{l}\text { Red } \\
\text { swamp }\end{array}$} & Tension contact & $1(5.26 \%)$ & n.o. & $1(5.26 \%)$ \\
\cline { 2 - 5 } & Active & n.o. & $5(26.32 \%)$ & $12(63.16 \%)$ \\
\cline { 2 - 5 } & Passive & n.o. & n.o. & n.o. \\
\hline
\end{tabular}

Both crayfish were simultaneously outside the shelter in 19 instances (6.09\%) during the whole experiment (Table V). In these situations, only the signal crayfish showed a passive behaviour. Differences between species in passive and non-passive behaviours were not significant (two-tailed Fisher exact test, $p=0.5439$ ). 


\section{DISCUSSION}

Although there are several laboratory studies dealing with the aggressive behaviour in crayfish, a few analysed shelter competition. Intraspecific competition has been studied both in P. leniusculus (RANTA and LINDSTROM, 1992, 1993; PEEKE et al., 1995) and in $P$. clarkii juveniles (FIGLER et al., 1999). Other works deal with interspecific competition between dyads composed of indigenous and nonindigenous species (SÖDERBACK, 1994; ELVEY et al., 1997; VORBURGER and RIBI, 1999; NAKATA and GOSHIMA, 2003; GHERARDI and DANIELS, 2004) and crayfish and freshwater crabs (GHERARDI and CIONI, 2004). As far as we know, this is the first study carried out between two nonindigenous crayfish, which behave as invasive species in southern Europe. Given the actual rate of dispersal of nonindigenous crayfish (HOLDICH, 2002), the contact between species is common in some European countries. In general, nonindigenous crayfish species were dominant in shelter competition over the native ones, although sometimes the reverse situation may be found, as demonstrated by ELVEY et al. (1997) between the indigenous Astacopsis franklinii and the nonindigenous yabby, Cherax destructor, in Tasmania. In our case, both species are known to expand their range by outcompeting other crayfish, either congeneric (i.e. Procambarus acutus acutus, Pacifastacus fortis) or not (Astacus astacus, Austropotamobius spp., Cambaroides japonicus) (SÖDERBACK, 1994; ELLIS, 1999; VORBURGER and RIBI, 1999; NAKATA and GOSHIMA, 2003; GHERARDI and DANIELS, 2004).

Red swamp crayfish occupy shelter more frequently than similarly sized signal crayfish and seems to behave more actively when out of it. In contrast with the other studies, it was difficult to predict the outcome of the experiment, since both crayfish species have been shown to be dominant in shelter competition when compared with other species (SÖDERBACK, 1994; NAKATA and GOSHIMA, 2003; GHERARDI and DANIELS, 2004), except in the study by VORBURGER and RIBI (1999). Certainly, a shortcome of our experiment is the lack of a control in which shelter occupancy is quantified within isolated crayfish. However, our preliminary observations did not reveal any difference in shelter use between species (nearly null for both). There is no information about the relative preference for shelter of red swamp and signal crayfish. Both are known to use shelters (GUAN, 1994; HUNER, 2002) and both dig burrows in the banks. Our results could be explained by a more aggressive behaviour of the red swamp crayfish, but can reflect other factors, such as differences in diel activity pattern during the study period or preferences for shelter (VORBURGER and RIBI, 1999; GHERARDI and CIONI, 2004). The frequency of initial wins by the red swamp crayfish was similar to that observed by ELVEY et al. (1997) with Astacopsis franklinii vs. same-sized Cherax destructor. While these authors found an increase in the frequency of long term wins, our study showed the opposite, suggesting that $P$. clarkii is slightly more effective in occupying the shelter quickly and slightly less to keep it for a long time. Interestingly, it should be noted that red swamp crayfish has less massive chelae than similarly sized signal crayfish, and that chela size has been shown to be related with crayfish potential to win in aggressive interactions (GARVEY et al., 1993).

Testing similarly sized individuals avoids a strong bias in shelter competition. On the other hand, it is likely that fights will be longer and more intense than usually observed in the field (BERGMAN and MOORE, 2003). Size is a good predictor of the outcome of aggressive encounters between crayfish and other decapods, bigger individuals being favoured (RANTA and LINDSTRÖM, 1992, 1993; PAVEY and FIELDER, 1996; FIGLER et al., 1999; TAKAHASHI et al., 2001 BERGMAN and MOORE, 2003). However, some authors did not find these differences (PEEKE et al., 1995; VORBURGER and RIBI, 1999). While PEEKE et al. (1995) explained their results from the small differences in size among the analysed crayfish (less than $2 \%$ in carapace length), VORBURGER and RIBI (1999) suggested that Austropotamobius torrentium had a higher preference for shelter than $P$. leniusculus. This is why smaller $A$. torrentium are able to successfully defend 
their shelters against bigger $P$. leniusculus. But higher preference could be insufficient to guarantee access to shelter. GHERARDI and DANIELS (2004) found that, although $P$. clarkii seemed to have less preference for the offered shelter when alone, it evicted and chased away $P$. a. acutus when the latter occupied the shelter.

Shelters are more valuable than food resources (BERGMAN and MOORE, 2003). Crayfish usually develop aggressive interactions to obtain and keep them (FIGLER et al., 1999). However, GHERARDI and DANIELS (2004) found that fights were less frequent in the presence of a shelter, although their duration was similar to that observed without shelters. In our work we detected very few tension contacts. This can be due to the method we adopted, with 30-min observations conducted during the light cycle, when fights are usually shorter than in the dark (BRUSKI and DUNHAM, 1987). Our experiment was designed to evaluate shelter use by the two species, rather than to study their agonistic behaviour. This is why our classification of behaviour is less complex than those used by other studies. In general, during the light phase both species show decreased activity levels. The absence of other stimuli might originate less need to shelter and so might reduce fights for its occupancy. On the contrary, the presence of predators increases aggressive contacts and induces changes in crayfish behaviour (SÖDERBACK, 1992; KELLER and MOORE, 2000), Although we tried to reduce the disturbance to crayfish to a minimum, we sometimes observed reactions from crayfish when removing the separators that could have influenced their first reactions towards the shelter. In $67 \%$ of trials, the long-term winner was the initial winner (Table III) and $58.3 \%$ of them occupied the shelter during the whole trial. Tension contacts were scarce. Signal crayfish outside the shelter showed a remarkable passive behaviour while red swamp crayfish were more active. This differed with what observed by GHERARDI and DANIELS (2004), who showed that $P$. clarkii, after having forced $P$. a. acutus to exit from the shelter, frequently did not occupy the vacant shelter but remained unsheltered. In our case, shelter occupancy for most time would suggest that the red swamp crayfish is not so overwhelming superior over signal crayfish as it is over $P$. a. acutus.

Our results should be interpreted with caution as the effect of a competitive advantage of male red swamp crayfish over signal crayfish. BERGMAN and MOORE (2003) warn about both extrinsic and intrinsic factors (aquaria size, presence of shelters, size and sex) that may change the intensity and dynamics of aggressive behaviour in the laboratory as compared with the natural setting. They conclude that aggressive behaviour should be examined in both the laboratory and the field. Different growth patterns and population size structure could change the predicted outcome of the encounters in the wild. In syntopic populations of both species in Central Spain, signal crayfish reach larger sizes than red swamp crayfish and a significant fraction of male $P$. leniusculus are bigger than their P. clarkii counterparts. A size advantage usually confers advantages in resource holding potential to the larger individuals (BERGMAN and MOORE, 2003). Habitat suitability, in particular shelter availability and types, may change also the outcome of interactions in the wild. Presently, most contacts in Spain are occurring in the upper reaches of the actual distribution of $P$. clarkii, both in small rivers with low temperatures, which seem more suitable to $P$. leniusculus and in lakes, reservoirs and bigger rivers not obviously so. For a better comprehension of the importance of shelter for the interaction between species, additional trials should be devised using differently sized individuals, females and juveniles. Besides, prior residence effects (PEEKE et al., 1995) should be tested and field observations should complete our laboratory studies.

\section{ACKNOWLEDGEMENTS}

We wish to thank Francisco Prieto and Orencio Sánchez for help on the catch and care of the crayfish used in this experiment. 
R. Martinez was supported by a grant of Servicio de Investigación Agraria, Junta de Comunidades de Castilla-La Mancha. Funding for this work was provided by Project SIA 01-189-RN-39 of the same institution.

\section{REFERENCES}

ALONSO F., TEMIÑO C., DIÉGUEZ-URIBEONDO J., 2000. Status of the white-clawed crayfish, Austropotamobius pallipes (Lereboullet, 1858), in Spain: Distribution and legislation. Bull. Fr. Pêche Pisci., 356, 31-54.

BERGMAN D.A., MOORE P.A., 2003. Field observations of intraspecific agonistic behaviour of two crayfish species, Orconectes rusticus and Orconectes virilis, in different habitats. Biol. Bull., 205, 26-35.

BLAKE M., NYSTROM P., HART P., 1994. The effect of weed cover on juvenile signal crayfish (Pacifastacus leniusculus Dana) exposed to adult crayfish and nonpredatory fish. Ann. Zool. Fenn., 31(3), 297-306.

BOVBJERG R.V., 1970. Ecological isolation and competitive exclusion in two crayfish (Orconectes virilis and Orconectes immunis). Ecology, 51, 225-236.

BRUSKI C.A., DUNHAM D.W., 1987. The importance of vision in agonistic communication of the crayfish Orconectes rusticus. Behaviour, 103, 83-107.

CHARLEBOIS P.M., LAMBERTI G.A., 1996. Invading crayfish in a Michigan stream: direct and indirect effects on periphyton and macroinvertebrates. J.N. Am. Benthol. Soc., 15 (4), 551-563.

CUELLAR L, CUELLAR M.C., 2000. Évolution de l'aphanomycose et repeuplements avec l'écrevisse signal (Pacifastacus leniusculus) en Espagne. L'Astaciculteur de France, 65, 2-9.

DIÉGUEZ-URIBEONDO J., TEMIÑO C., MÚZQUIZ J.L., 1997. The crayfish plague fungus in Spain. Bull. Fr. Pêche Pisci., 347, 753-763.

ELLIS M.J., 1999. Species invasions and replacements in a native crayfish community. Ph.D. University of Michigan, $216 \mathrm{p}$.

ELVEY W., RICHARDSON A.M.M., BARMUTA L., 1997. Interactions between the introduced yabby, Cherax destructor, and the endemic crayfish, Astacopsis franklinii, in Tasmanian streams. Freshwater Crayfish, 11, 349-363.

FIGLER M.H., CHEVERTON H.M., BLANK G.S., 1999. Shelter competition in juvenile red swamp crayfish (Procambarus clarkii): the influences of sex differences, relative size and prior residence. Aquaculture, 178, 63-75.

GARVEY J.E., STEIN R.A., THOMAS H.M., 1993. Evaluating how chela size influences the invasion potential of an introduced crayfish (Orconectes rusticus). Am. Midl. Nat., $129,172-181$.

GARVEY J.E., STEIN R.A., THOMAS H.M., 1994. Assessing how fish predation and interspecific prey competition influence a crayfish assemblage. Ecology, 75, 2, 532-547.

GHERARDI F., 2002. Behaviour. In: HOLDICH D.M. (ed.) Biology of freshwater crayfish. Blackwell Science, 258-290.

GHERARDI F., BARBARESI S., RADDI A., 1999. The agonistic behaviour of red swamp crayfish Procambarus clarkii: functions of the chelae. Freshwater Crayfish, 12, 233243. 
GHERARDI F., CIONI A., 2004. Agonism and interference competition in freshwater decapods. Behaviour, 141, 1297-1324.

GHERARDI F., DANIELS W.H., 2004. Agonism and shelter competition between invasive and indigenous crayfish species. Canadian Journal of Zoology, 82 (12), 19231932.

GUAN R., 1994. Burrowing behaviour of signal crayfish, Pacifastacus leniusculus (Dana), in the river Great Ouse, England. Freshwater Forum, 4, 3, 155-168.

GUAN R., WILES P.R., 1997. Ecological impact of introduced crayfish on benthic fishes in a British lowland river. Conservation Biology, 11 (3), 641-647.

GUIASU R.D., DUNHHAM D.W., BARR D. W., 1997. Interespecific agonistic contests between male, Cambarus bartonii bartonii (Fabricius, 1798) and Cambarus robustus (Girard 1852) crayfish and the possible competition between the two species in Ontario. Freshwater Crayfish, 11, 364- 377.

HILL A.M., LODGE D.M., 1994. Diel changes in resource demand: Competition and predation in species replacement among crayfishes. Ecology, 75, 7, 2118-2126.

HILL A.M., LODGE D.M., 1999. Replacement of resident crayfishes by an exotic crayfish: the roles of competition and predation. Ecological Applications, 9 (2), 678-690.

HOLDICH D.M., 2002. Distribution of crayfish in Europe and some adjoining countries. Bull. Fr. Pêche Piscic., 367, 611-650.

HOLDICH D.M., DOMANIEWSKI J.C.J., 1995. Studies on a mixed population of the crayfish Austropotamobius pallipes and Pacifastacus leniusculus in England. Freshwater Crayfish, 10, 37-45.

HUNER J.V., 2002. A brief description of the burrows of the commercial procambarid crayfishes in Louisiana research and demonstration ponds. Freshwater Crayfish, 13, 247-252.

HUNER J.V., BARR J.E., 1991. Red swamp crayfish: biology and exploitation. Lousiana Sea Grant College Program. Lousiana State University, Baton Rouge.

KELLER T.A., MOORE A.P., 2000. Context-specific behaviour: crayfish size influences crayfish-fish interactions. J.N. Am. Benthol. Soc., 19(2), 344-351.

LEVENBACH S., HAZLETT B.A., 1996. Habitat displacement and the mechanical and display functions of chelae in crayfish. Journal of Freshwater Ecology, 11, 485492.

LIGHT T., 2005 Behavioural effects of invaders: alien crayfish and native sculpin in a California stream. Biological Invasions, 7 (3), 353-367.

LINDQVIST O.V., HUNER J.V., HENTONNEN P., KÖNÖNEN,H., 1999. A comparison of life story strategies and energy reserves of crayfishes occupying permanent and temporary water bodies. Freshwater Crayfish, 12, 449-461.

NAKATA K., GOSHIMA S., 2003. Competition for shelter of preferred sizes between the native crayfish species Cambaroides japonicus and the alien crayfish species Pacifastacus leniusculus in Japan in relation to prior residence, sex difference, and body size. Journal of Crustacean Biology, 23 (4), 897-907.

PAVEY C.R., FIELDER D.R., 1996. The influence of size differential on agonistic behaviour in the freshwater crayfish, Cherax cuspidatus (Decapoda: Parastacidae). Journal of Zoology, 238, 445-458.

PEEKE H.V.S., SIPPEL J., FIGLER M.H., 1995. Prior residence effects in shelter defence in adult signal crayfish (Pacifastacus leniusculus (Dana)): Results in same- and mixedsex dyads Crustaceana, 6 (8), 873-881. 
RANTA E., LINDSTRÖM K., 1992. Power to hold sheltering burrows by juveniles of the signal crayfish, Pacifastacus leniusculus. Ethology, 92, 217-226.

RANTA E., LINDSTRÖM K., 1993. Body size and shelter possesion in mature signal crayfish, Pacifastacus leniusculus. Ann. Zool. Fenn., 30, 125-132.

SÖDERBACK B., 1994. Reproductive interference between two co-occurring crayfish species, Astacus astacus (L.) and Pacifastacus leniusculus (Dana) North. J. Fresh. Res., 69, 137-143.

SÖDERBACK B., 1992. Predator avoidance and vulnerability of two co-occurring crayfish species, Astacus astacus (L.) and Pacifastacus leniusculus (Dana) Ann. Zool. Fenn., 29, $253-259$.

STENROTH P., NYSTROM P., 2003. Exotic crayfish in a brown water stream: effects on juvenile trout, invertebrates and algae. Freshwater Biology, 48, 466-475.

TAKAHASHI M., SUZUKI N., KOGA T., 2001. Burrow defense behaviors in a sand-bubbler crab, Scopimera globosa, in relation to body size and prior residence. J. Ethol., 19, 93-96.

VORBURGER C., RIBI G., 1999. Pacifastacus leniusculus and Austropotamobius torrentium prefer different substrates. Freshwater Crayfish, 12, 696-704. 
